\title{
Genetic Distances of Paralichthys olivaceus Populations Investigated by PCR
}

\author{
$\dagger$ Jong-Man Yoon \\ Dept. of Aquatic Life Medicine, College of Ocean Science and Technology, \\ Kunsan National University, Gunsan 54150, Korea
}

\begin{abstract}
The author carried out PCR-based genetic platform to investigate the hierarchical polar dendrogram of Euclidean genetic distances of one bastard halibut population, particularly for Paralichthys olivaceus, which was further connected with those of the other fish population, by involving with the precisely designed oligonucleotide primer sets. Eight oligonucleotides primers were used generating excessively alterating fragments, ranging in size of DNA bands from larger than approximately $100 \mathrm{bp}$ to less than $2,000 \mathrm{bp}$. As regards average bandsharing value (BS) results, individuals from Hampyeong population (0.810) displayed lower bandsharing values than did individuals from Wando population (0.877). The genetic distance between individuals approved the existence of close relationship in the cluster II. Relatively, individuals of one bastard halibut population were fairly related to that of the other fish population, as shown in the polar hierarchical dendrogram of Euclidean genetic distances. The points of a noteworthy genetic distance between two $P$. olivaceus populations demonstrated this PCR procedure is one of the quite a few means for individuals and/or populations biological DNA investigates, for species security and proliferation of bastard halibut individuals in coastal region of the Korea.
\end{abstract}

Key words : Euclidean genetic distances, Polar dendrogram, Bastard halibut population

\section{INTRODUCTION}

Paralichthys olivaceus is commercially important teleost species, belonging to family Paralichthyidae, order Pleuronectiformes, broadly distributed on the seashore of the Yellow Sea, southern sea and the Jeju Island of Korea, Chinese sea and Japanese sea. In the environment, the fishes inhabit the benthic flats consisting of a lot of sand and slime. Like other fishes, the rate at which the fish grows, is greatly influenced by water quality. The outer body color of this fish is yellowish and/or body color is black and grey. The color of the abdomen is yellowish brown or light white. Mainly, there are marked shifts of the fish weight, size, color and shape in P. olivaceus in keeping with the ecological surroundings of habitat such as prey, rock crystal, water temperature, feed and harsh period. The bastard halibut is environmentally and biologically very important fishes in the Korea. However, this kind of finfish, which are well-known important environmentally (Bae et al., 2017), physiologically (Kim et al., 2018), histopathologically (Kim et al., 2017), as well as aquaculturally (Lee \& Yoo, 2016) are not genetically and/or molecular-biologically studied comparable other fishes. There is a necessity to understand the genetic traits and composition of this finfish population in order to evaluate exactly the patent genetic significance. PCR-based molecular research

\footnotetext{
Manuscript received July 27, 2018, Received in revised form August 22, 2018, Accepted September 5, 2018

${ }^{\dagger}$ Corresponding Author : Jong-Man Yoon, Dr. Prof., Dept. of Aquatic Life Medicine, College of Ocean Science and Technology, Kunsan National University, Gunsan 54150, Korea. Tel: +82-63-469-1887, E-mail: jmyoon@kunsan.ac.kr
} creative-commons.org/licenses/by-nc/3.0) which permits unrestricted non-commercial use, distribution, and reproduction in any medium, provided the original work is properly cited. 
methods have been applied to study the genetic characters of various finfishes and shellfishes (Partis \& Wells, 1996; Callejas \& Ochando, 1998; Tassanakajon et al., 1998; Muchmore et al., 1998; McCormack et al., 2000; Zhou et al., 2000; Chenyambuga et al., 2004; Yoon \& Park 2002; Islam et al., 2005; Oh \& Yoon, 2014). Generally, the markers peculiar to the species, the genus or the geographical populations have been applied for the individuals and species, hybrid parentage and for the monitoring of DNA markers. Here, to clarify the Euclidean genetic distances in bastard halibut, the author undertook the clustering analyses of two geographical populations of bastard halibut ( $P$. olivaceus) raising in the Hampyeong and Wando, respectively.

\section{MATERIALS AND METHODS}

PCR analysis was accomplished on DNA samples extracted from a total of 22 individuals using eight oligonucleotides primers. DNA extraction should be performed along with the separation and extraction methods (Yoon \& Kim, 2004). $600 \mu \mathrm{L}$ of chloroform was added to the mixture and then inverted (no phenol). After quite a few washing, the lysis buffer I $\left(155 \mathrm{mM} \mathrm{NH}_{4} \mathrm{Cl} ; 10 \mathrm{mM} \mathrm{KHCO}_{3} ; 1\right.$ mM EDTA) was augmented to samples, and the mixture tubes were gently upset. The precipitates obtained were centrifuged and suspended with lysis buffer II $(10 \mathrm{mM}$ Tris-HCl, pH 8.0; 10 mM EDTA; $100 \mathrm{mM} \mathrm{NaCl;0.5 \%}$ SDS) and added $15 \mu \mathrm{L}$ proteinase $\mathrm{K}$ solution $(10 \mathrm{mg} / \mathrm{mL})$. After incubation, there was added $300 \mu \mathrm{L}$ of $3 \mathrm{M} \mathrm{NaCl}$ and gently pipetted for a few of min. Added not phenol, $600 \mu \mathrm{L}$ of chloroform were added to the mixture and then inverted. Ice-cold $70 \%$ EtOH was added, and then the samples were centrifuged at 19,621 $\mathrm{g}$ for $5 \mathrm{~min}$ to extract the DNA from the lysates. The concentration of the extracted genomic DNA was measured with the optical density (OD) at 260 $\mathrm{nm}$ by a spectrophotometer (Beckman Coulter, Buckinghamshire, UK). The DNA pellets were then incubationdried for more than 12 hours, maintained at $-70^{\circ} \mathrm{C}$ until needed and then dissolved in the distilled water. The DNA amplification was performed in $25 \mu \mathrm{L}$ containing $10 \mathrm{ng}$ of template DNA, $20 \mu \mathrm{L}$ premix (Bioneer Co., Daejeon, Korea) and the 1.0 unit primer. Amplification products were separated by $1.4 \%$ agarose (Bioneer Co., Daejeon, Korea) gel electrophoresis with TBE (90 mM Tris, $\mathrm{pH} 8.5 ; 90 \mathrm{mM}$ borate; $2.5 \mathrm{mM}$ EDTA). The 100 bp DNA ladder (Bioneer Co., Daejeon, Korea) was used as DNA molecular weight marker. The agarose gels electrophoresed were stained with ethidium bromide (Song \& Yoon, 2013). The electrophoresed agarose gels were illuminated by ultraviolet rays, and photographed using a photoman direct copy system (PECA Products, Beloit, WI, USA). The oligonucleotides primer were acquired from Operon Technologies, USA. OPA-02 (5'-TGCCGAGCTG-3'), OPA-07 (5'-GAAACG GGTG-3'), OPA-18 (5'-AGGTGACCGT-3'), OPA-20 (5'GTTGCGATCC-3'), OPB-08 (5'-GTCCACACGG-3'), OPB-09 (5'-TGGGGGACTC-3'), OPB-15 (5'-GGAGGG TGTT-3'), and OPB-17 (5'-AGGGAACGAG-3') were displayed to yield the bandsharing values and genetic distances of the two bastard halibut populations. PCR was carried out using programmable DNA Thermal Cycler Cycler (MJ Research Inc., Waltham, MA, USA). Similarity matrix including bandsharing values between dissimilar individuals in the two P. olivaceus populations, was generated allowing formula of Jeffreys and Morton (1987) and YokeKqueen and Radu (2006). A hierarchical clustering tree was accumulated using similarity matrices to yield a dendrogram, which was supported by the Systat version 10 (SPSS Inc., Chicago, IL, USA).

\section{RESULTS AND DISCUSSION}

In this study, the bandsharing value, which is based on the presence or absence of amplified fragments, was utilized to calculate similarity indices in two bastard halibut populations, as demonstrated in Table 1. Here, the complexity of the banding patterns varied dramatically be- 
Table 1. Trigonal similarity matrix containing bandsharing values calculated using Nei and Li's index of the similarity of two bastard halibut (P. olivaceus) populations from Hampyeong and Wando, respectively

\begin{tabular}{|c|c|c|c|c|c|c|c|c|c|c|c|c|c|c|c|c|c|c|c|c|c|c|}
\hline \multicolumn{12}{|c|}{ Bandsharing values of Hampyeong population } & \multicolumn{11}{|c|}{ Bandsharing values of Wando population } \\
\hline & 1 & 2 & 3 & 4 & 5 & 6 & 7 & 8 & 9 & 10 & 11 & 12 & 13 & 14 & 15 & 16 & 17 & 18 & 19 & 20 & 21 & 22 \\
\hline 1 & - & 0.831 & 0.816 & 0.831 & 0.76 & 0.738 & 0.801 & 0.713 & 0.724 & 0.794 & 0.740 & 0.659 & 0.560 & 0.550 & 0.605 & 0.603 & 0.623 & 0.564 & 0.568 & 0.538 & 0.592 & 0.549 \\
\hline 2 & & - & 0.847 & 0.838 & 0.859 & 0.800 & 0.82 & 0.774 & 0.810 & 0.786 & 0.731 & 0.562 & 0.567 & 0.591 & 0.613 & 0.654 & 0.642 & 0.611 & 0.609 & 0.569 & 0.635 & 0.625 \\
\hline 3 & & & - & 0.906 & 0.785 & 0.768 & 0.802 & 0.719 & 0.751 & 0.707 & 0.677 & 0.572 & 0.572 & 0.532 & 0.512 & 0.546 & 0.609 & 0.582 & 0.548 & 0.548 & 0.570 & 0.557 \\
\hline 4 & & & & - & 0.805 & 0.807 & 0.817 & 0.759 & 0.793 & 0.771 & 0.757 & 0.52 & 0.553 & 0.504 & 0.488 & 0.522 & 0.559 & 0.537 & 0.501 & 0.496 & 0.519 & 0.511 \\
\hline 5 & & & & & - & 0.918 & 0.86 & 0.891 & 0.831 & 0.789 & 0.751 & 0.551 & 0.554 & 0.544 & 0.560 & 0.596 & 0.614 & 0.565 & 0.586 & 0.523 & 0.584 & 0.589 \\
\hline 6 & & & & & & - & 0.918 & 0.907 & 0.867 & 0.785 & 0.767 & 0.554 & 0.528 & 0.536 & 0.548 & 0.590 & 0.554 & 0.535 & 0.510 & 0.473 & 0.528 & 0.519 \\
\hline 7 & & & & & & & - & 0.845 & 0.84 & 0.827 & 0.761 & 0.504 & 0.506 & 0.468 & 0.483 & 0.544 & 0.537 & 0.516 & 0.515 & 0.477 & 0.536 & 0.526 \\
\hline 8 & & & & & & & & - & 0.987 & 0.907 & 0.828 & 0.528 & 0.554 & 0.517 & 0.532 & 0.562 & 0.556 & 0.560 & 0.557 & 0.498 & 0.554 & 0.592 \\
\hline 9 & & & & & & & & & - & 0.894 & 0.815 & 0.566 & 0.541 & 0.53 & 0.545 & 0.576 & 0.568 & 0.573 & 0.569 & 0.511 & 0.567 & 0.557 \\
\hline 10 & & & & & & & & & & - & 0.921 & 0.613 & 0.575 & 0.567 & 0.621 & 0.618 & 0.610 & 0.610 & 0.611 & 0.587 & 0.635 & 0.622 \\
\hline 11 & & & & & & & & & & & - & 0.568 & 0.545 & 0.575 & 0.624 & 0.589 & 0.580 & 0.556 & 0.556 & 0.557 & 0.578 & 30.568 \\
\hline 12 & & & & & & & & & & & & - & 0.823 & 0.757 & 0.824 & 0.770 & 0.784 & 0.808 & 0.764 & 0.844 & 0.839 & 0.792 \\
\hline 13 & & & & & & & & & & & & & - & 0.870 & 0.885 & 0.896 & 0.889 & 0.878 & 0.853 & 0.858 & 0.852 & 20.895 \\
\hline 14 & & & & & & & & & & & & & & - & 0.922 & 0.879 & 0.896 & 0.863 & 0.891 & 0.818 & 0.859 & 0.824 \\
\hline 15 & & & & & & & & & & & & & & & - & 0.951 & 0.930 & 0.891 & 0.899 & 0.880 & 0.867 & 0.849 \\
\hline 16 & & & & & & & & & & & & & & & & - & 0.980 & 0.935 & 0.923 & 0.878 & 0.889 & 0.878 \\
\hline 17 & & & & & & & & & & & & & & & & & - & 0.955 & 0.943 & 0.899 & 0.909 & 0.898 \\
\hline 18 & & & & & & & & & & & & & & & & & & - & 0.937 & 0.892 & 0.808 & 30.908 \\
\hline 19 & & & & & & & & & & & & & & & & & & & - & 0.900 & 0.940 & 0.943 \\
\hline 20 & & & & & & & & & & & & & & & & & & & & - & 0.887 & 0.911 \\
\hline 21 & & & & & & & & & & & & & & & & & & & & & - & 0.915 \\
\hline 22 & & & & & & & & & & & & & & & & & & & & & & - \\
\hline
\end{tabular}

tween the primers from the two finfish populations. The similarity matrix, which was bas ed on the average bandsharing value of all the samples, ranged from 0.677 to 0.987 in the Hampyeong population and $0.757-0.980$ to the Wando population. The bandsharing value between individuals no. 08 and no. 09 within the Hampyeong population (P. olivaceus) was 0.987 , which was the highest value identified among the two populations. As regards average bandsharing value (BS) results, individuals from Hampyeong population (0.810) displayed lower bandsharing values than did individuals from Wando population (0.877). The average bandsharing value reported by this study is similar to the value ported for Spanish barbell species (0.71-0.81) (Callejas \& Ochando, 1998). The average bandsharing value recorded in our study is also higher than the average value between the bullhead population ( $0.504 \pm$ 0.115) (Yoon \& Kim, 2004). In the present study, the hierarchical polar dendrogram obtained by the eight oligonucleotides primers designates two genetic clusters: cluster

Table 2. Multiple calculations of average bandsharing values (mean \pm SE) between two bastard halibut populations were generated in keeping with the bandsharing values and similarity matrix.

\begin{tabular}{ccc}
\hline \hline Population & Hampyeong & Wando \\
\hline Hampyeong & $0.810 \pm 0.009^{\mathrm{a}}$ & $0.560 \pm 0.004^{\mathrm{b}}$ \\
Wando & - & $0.877 \pm 0.007^{\mathrm{a}}$
\end{tabular}

${ }^{\mathrm{a}, \mathrm{b}}$ Values with different superscript are significantly different, $p<0.05$.

Each value is a result of three different experiments. 


\section{Cluster Tree}

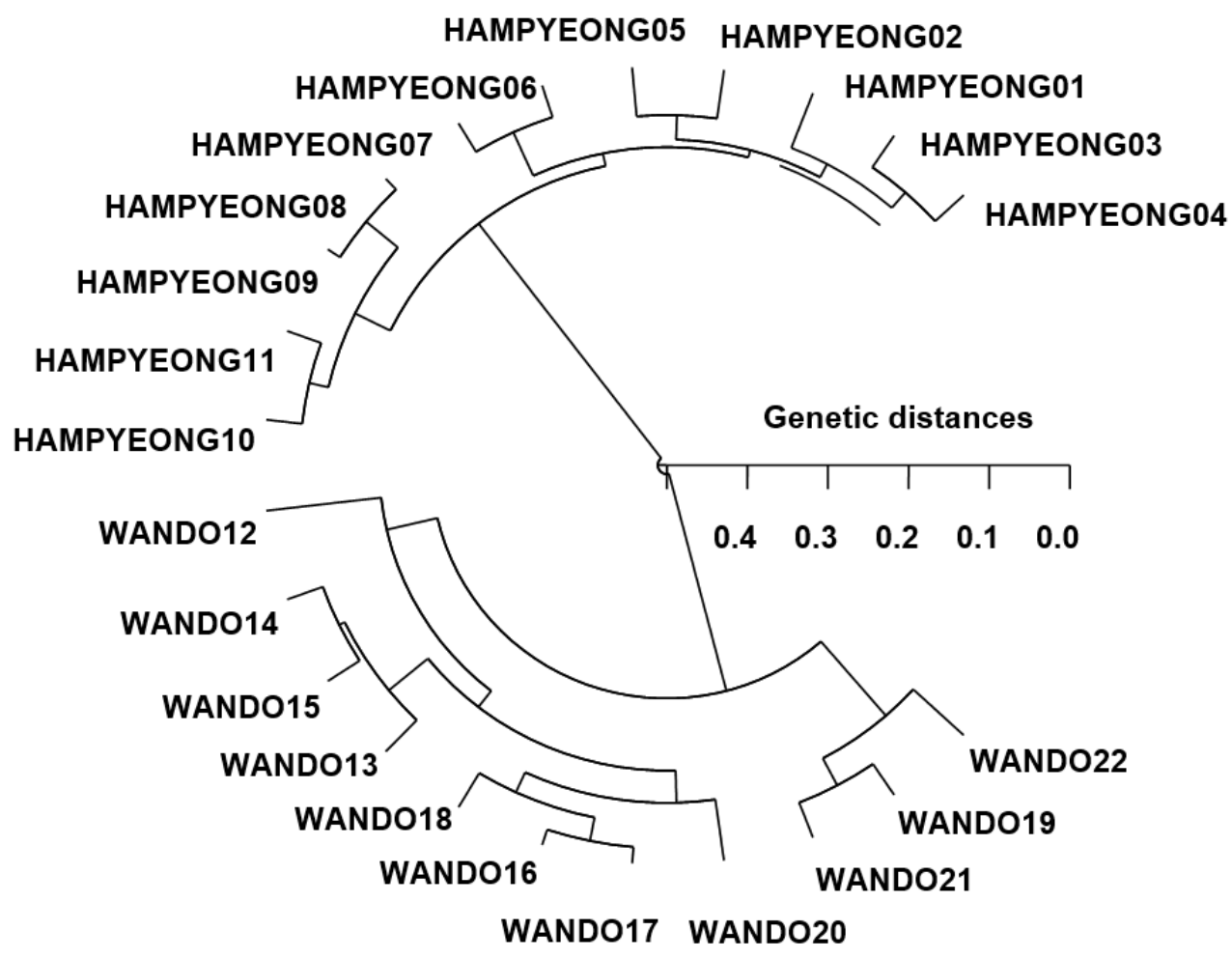

Fig. 1. Hierarchical polar dendrogram of genetic distances obtained from two Paralichthys olivaceus populations. The relatedness between dissimilar individuals of two bastard halibut populations from cluster I (HAMPYEONG 01 02, 03, 04, 05, 06, 07, 08, 09, 10, and 11) and cluster II (WANDO 12, 13, 14, 15, 16, 17, 18, 19, 20, 21, and 22) generated according to the bandsharing values and similarity matrix.

1 (HAMPYEONG 01, 02, 03, 04, 05, 06, 07, 08, 09, 10, and 11 ) and cluster 2 (WANDO 12, 13, 14, 15, 16, 17, 18, 19, 20, 21, and 22) (Fig. 1). Among the twenty-two fishes, the shortest genetic distance that demonstrated significant molecular differences was between individuals fish no. 09 and no. 08 from the cluster I (genetic distance $=0.018$ ), while the longest genetic distance among the twenty-two individuals that exhibited significant molecular differences was between individuals fish no. 05 and clam no. 20 (genetic distance $=0.489$ ). Relatively, individuals of cluster I were greatly closely related to that of cluster II, as shown in the polar dendrogram of Euclidean genetic distances. The genetic distance between individuals approved the existence of close relationship in the cluster II. The values of the pairwise comparisons of unbiased genetic distance between the populations of the Indian major carp (Catla catla) from the combined data for the four primers, ranged from 0.025 to 0.052 (Islam et al., 2005). They reported that the Padma and the Jamuna populations were separated from each other with the lowest genetic distance $(D=$ 0.025). From what has been said above, the prospective of this research method in determining the diagnostic markers for the breed, stock, species, genus and geographic population identification in teleost (Mamuris et al., 1999; DiazJaimes \& Uribe-Alcocer, 2003), in shellfish (Tassanakajon et al., 1998; McCormack et al., 2000; Oh \& Yoon, 2014) and in livestock (Jeffreys \& Morton, 1987; Gwakisa et al., 1994) has also been established. The points of a significant 
genetic distance between two $P$. olivaceus populations demonstrated this PCR means is one of the several devices for individuals and/or populations biological DNA investigates.

\section{ACKNOWLEDGEMENTS}

The author would like to thank the referees who aided with thorough and shrewd revision. Particular appreciations go to our laboratory colleagues and undergraduate students for their supports for their assistance in sampling, and their helps with the preparation of PCR investigation and statistical analyses during the course of this research procedures.

\section{REFERENCES}

Bae SH, Kim KW, Kim SK, Kim JH, Kim JH (2017) Lethal toxicity and hematological changes exposed to nitrate in flatfish, Paralichthys olivaceus in biofloc and seawater. Environ Biol Res 35:373-379.

Callejas C, Ochando MD (1998) Identification of Spanish barbel species using the RAPD technique. J Fish Biol 53:208-215.

Chenyambuga SW, Hanotte O, Hirbo J, Watts PC, Kemp SJ, Kifaro GC, Gwakisa PS, Petersen PH, Rege JEO (2004) Genetic characterization of indigenous goats of sub-Saharan Africa using microsatellite DNA markers. Asian-Australas J Anim Sci 17:445-452.

Diaz-Jaimes P, Uribe-Alcocer M (2003) Allozyme and RAPD variation in the eastern Pacific yellowfin tuna (Thunnus albacares). Fish Bull 101:769-777.

Gwakisa PS, Kemp SJ, Teale AJ (1994) Characterization of zebu cattle breeds in Tanzania using random amplified polymorphic DNA markers. Anim Genet 25:89-94.

Islam MS, Ahmed ASI, Azam MS, Alam MS (2005) Genetic analysis of three river populations of Catla catla (HAMILTON) using randomly amplified polymorphic
DNAs markers. Asian-Australas J Anim Sci 18:453457.

Jeffreys AJ, Morton DB (1987) DNA fingerprints of dogs and cats. Anim Genet 18:1-15.

Kim SR, Ko SM, Choi H, Park JJ (2017) The first report of marine leech, Austrobdella sp. parasited on the wild flounder, Paralithytis olivaceus and histopathological characteristics of the host. J Fish Mar Sci Edu 29:13941404.

Kim JY, Sung GH, Lim JJ, Suo SA, Cho YR, Kim JH (2018) Effects of exposure to hexavalent chromium on hematological parameters and plasma components in flatfish, Paralichthys olivaceus. Korean J Environ Biol $36: 124-130$

Lee HY, Yoo HK (2016) Effects of various diets on growth and body composition of juvenile olive flounder, $\mathrm{Pa}$ ralichthys olivaceus. Korean J Ichthyol 28:200-206.

Mamuris Z, Stamatis C, Bani M, Triantaphyllidis C (1999) Taxonomic relationships between four species of the Mullidae family revealed by three genetic methods: Allozymes, random amplified polymorphic DNA and mitochondrial DNA. J Fish Biol 55:572-587.

McCormack GP, Powell R, Keegan BF (2000) Comparative analysis of two populations of the brittle star $\mathrm{Am}$ phiura filiformis (Echinodermata: Ophiuroidae) with different life history strategies using RAPD markers. Mar Biotechnol 2:100-106.

Muchmore ME, Moy GW, Swanson WJ, Vacquier VD (1998) Direct sequencing of genomic DNA for characterization of a satellite DNA in five species of Eastern Pacific abalone. Mol Mar Biol Biotechnol 7:1-6.

Oh H, Yoon JM (2014) Genetic distances of three mollusk species investigated by PCR analysis. Dev Reprod 18: 43-49.

Partis L, Wells RJ (1996) Identification of fish species using random amplified polymorphic DNA (RAPD). Mol Cell Probes 10:435-441.

Song YJ, Yoon JM (2013) Genetic differences of three 
Pollicipes mitella population identified by PCR analysis. Dev Reprod 17:199-205.

Tassanakajon A, Pongsomboon S, Jarayabhand P, Klinbunga S, Boonsaeng V (1998) Genetic structure in wild populations of black tiger shrimp (Penaeus monodon) using randomly amplified polymorphic DNA analysis. J Mar Biotechnol 6:249-254.

Yoon JM, Park HY (2002) Genetic similarity and variation in the cultured and wild crucian carp (Carassius carassius) estimated with random amplified polymorphic DNA. Asian-Australas J Anim Sci 15:470-476.

Yoon JM, Kim JY (2004) Genetic differences within and between populations of Korean catfish (S. asotus) and bullhead (P. fulvidraco) analysed by RAPD-PCR. AsianAustralas J Anim Sci 17:1053-1061.

Yoke-Kqueen C, Radu S (2006) Random amplified polymorphic DNA analysis of genetically modified organisms. J Biotechnol 127:161-166.

Zhou L, Wang Y, Gui JF (2000) Analysis of genetic heterogeneity among five gynogenetic clones of silver crucian carp, Carassius auratus gibelio Block, based on detection of RAPD molecular markers. Cytogenet Cell Genet 88:133-139. 